Brief Research Report

\title{
Epidemiology of Coronavirus Disease 2019 in Mexico: A Report on Age-Sex Variation in the Duration from Symptom Onset to Fatality as an Outcome in Patients
}

Sofía E.Aguiñaga-Malanco, BSc'; Sudip Datta-Banik, PhD ${ }^{*}$; Rudradeep Datta-Banik, [Student $]^{2}$; Nina Mendez-Dominguez, PhD ${ }^{2}$

'Department of Human Ecology, Cinvestav-IPN, Merida, Yucatan, Mexico

${ }^{2}$ Department of Health Sciences, Universidad Marista, School of Medicine, Merida, Yucatan, Mexico

\section{*Corresponding author}

Sudip Datta-Banik, PhD

Department of Human Ecology, Cinvestav-IPN, Merida,Yucatan, Mexico; E-mail: dattabanik@cinvestav.mx

\section{Article information}

Received: September 10 ${ }^{\text {th }}, 2020$; Revised: October 26 $6^{\text {th }}$, 2020; Accepted: October 27 th 2020 ; Published: November $18^{\text {th }}, 2020$

\section{Cite this article}

Aguiñaga-Malanco SE, Datta-Banik S, Datta-Banik R, Mendez-Dominguez N. Epidemiology of coronavirus disease 2019 in Mexico:A report on age-sex variation in the duration from symptom onset to fatality as an outcome in patients. Anthropol Open J. 2020; 4(I): 20-23. doi: I0.17/40/ANTPOJ-4-I22

\section{ABSTRACT}

\section{Objective}

To describe age-sex differences in the duration from symptom onset to fatality as an outcome in coronavirus desease 2019 (COVID-19) patients.

Methods

The Mexican surveillance system database (up to $15^{\text {th }}$ August 2020) of 70,515 death cases (45,053 males, 25,462 females) in COVID-19 was used for analysis. Age groups for pediatric patients were $<1,1-4,5-9$-years and for the adolescent and adult patients, each decade of life constituted an age group.

Results

Proportionally more deaths occurred among male patients (64\%). Median duration was eight days from onset of symptoms until death; mean value was approximately 10-days. Distribution by age groups showed females survived lower number of average days after the onset of symptoms. A tendency of rise in the number of days survived has been observed from infancy to adulthood and a subsequent decline after 70 -years of age.

\section{Conclusion}

Female patients survived relatively lower number of days with infection until death, compared to males.

\section{Keywords}

COVID-19; Infection; Sex difference; Survival; Death.

\section{INTRODUCTION}

$\mathrm{n}$ astounding increase in the number of infected cases and Adeaths due to coronavirus desease 2019 (COVID-19) since December 2019 and sex differences in incidence rates have been reported from different countries, including Mexico. ${ }^{1-3}$ Until $15^{\text {th }}$ August 2020, COVID-19 had a global impact excluding Antarctica, with 21,175,662 confirmed cases and around 759,629 deaths; an overall rate of death was approximately $3.59 \% .^{3}$ Mexico, with an approximate frequency of $11 \%$ death in COVID-19, has been added to the list of the most vulnerable countries in terms of epidemiology of the disease. Other countries that reported remarkable prevalence of death due in COVID-19 in- clude France (11.86\%), Italy (13.29\%), and Belgium (11.7\%). Relatively lower prevalence of death was reported from Spain (6.6\%), China (5.23\%), Brazil (3.14\%), and the U.S.A. $(3.09 \%)$.

Starting from the first reported case in Mexico in January 2020, Ministry of Health reported a total of 544,012 accumulated confirmed cases on $15^{\text {th }}$ August. ${ }^{4}$ The COVID-19 incidence in Mexico was 13.89 per 100,000 inhabitants, across the 32 Mexican States, with a hospital recovery rate around $72 \% .^{2,5}$

After being in contact with an infective case of COVID-19, host's immune system encounters severe acute respiratory syndrome coronavirus 2 (SARS-CoV-2) virus and develops signs 
and symptoms of COVID-19; then the patients seek for attention. Once receiving medical attention, patients may be considered as suspected cases (not laboratory tested, as part of the sentinel surveillance strategy) or they may be confirmed through laboratory tests. When patients develop severity, clinical manifestations including dyspnea or pneumonia, they are triaged to be assisted ambulatorily or hospitalized.

Susceptibility to death in COVID-19 is associated with comorbidities such as cardiovascular, respiratory, chronic kidney diseases, diabetes, etc. ${ }^{5}$ In addition, severity enhanced the complications; $66.5 \%$ of COVID-19 patients in Mexico developed pneumonia. ${ }^{5}$ A study from the US reported the duration of hospitalization of the COVID-19 survivors and non-survivors; the estimated median value of duration of stay (either hospitalized or in home quarantine) was 9.3-days among survivors (0.8 to 32.9-days) and 12.7-days (1.6 to 37.7-days) among non-survivors. ${ }^{6}$ Similar report was not available from Mexico.

In this background, the present study aims to describe age-sex differences in the duration from symptom onset to fatality as an outcome in COVID-19 patients.

\section{MATERIALS AND METHODS}

In this descriptive study, the Mexican surveillance system COVID-19 database up to $15^{\text {th }}$ August 2020 was used (retrieved from the official website of the Federal Government of Mexico. ${ }^{7}$ The study did not require ethical clearance of any Institutional Review Board. Total number of registered cases (hospitalized and ambulatory) was $10,48,575\left(5,23,123\right.$ males, 5,25,452 females) between $1^{\text {st }}$ January and $15^{\text {th }}$ August 2020. Total number of deaths registered during this period was 70,515 cases (45,053 males, 25,462 females). Number of days that the patients were alive have been estimated from the first day of symptom reported by the patient until death. Age groups for pediatric patients were $<1,1-4,5-9$-years and for adolescent and adults, each decade of life constituted an age group. Statistical software Statistical Package for the Social Sciences (SPSS) (Version 15.0) was used for data analysis that provided descriptive results (mean, median, and standard deviation values) of the duration (onset of symptoms to fatality) by age groups and sex. Sex difference of duration was tested using Student's $t$-test. Association of such duration with age and sex has been estimated using correlation analysis (Pearson's and point biserial correlation coefficient). Statistical significance was set a priori at $p<0.05$ in all analyses.

\section{RESULTS}

Average number of days from onset of symptom to fatality as outcome (termed as 'duration') was 9.91, ranging between zero and 105.13-days. The average duration among male patients (10.03 \pm 6.95 -days) was longer than that estimated among females (9.70 \pm 7.09 -days); median value was 8.21 -days (Table 1$)$. Sex difference of duration that the patients were alive was significant $(p<0.05)$ in the age groups 20-29-years ( $t=3.07), 30$-39-years $(t=2.66), \quad 40-49$-years $(t=2.16), \quad 70-79$-years $\quad(t=3.04)$, and 80-89-years $(t=3.18)$. Negative correlation between duration and age was significant $(\mathrm{r}=-0.03, p<0.05)$ in male and female patients. The value of the coefficient was apparently low that was related to the sample size.

\begin{tabular}{|c|c|c|c|c|c|c|}
\hline $\begin{array}{l}\text { Age Group } \\
\text { (years) }\end{array}$ & Sex & $\mathbf{n}$ & Mean & SD & Median & Days* \\
\hline \multirow{2}{*}{ All age } & Male & 45053 & 10.03 & 6.96 & 8.21 & 101.85 \\
\hline & Female & 25462 & 9.70 & 7.09 & 8.21 & 105.13 \\
\hline \multirow{2}{*}{ Belowl-year } & Male & 112 & 6.71 & 7.31 & 4.11 & 33.68 \\
\hline & Female & 72 & 5.85 & 6.52 & 3.29 & 38.60 \\
\hline \multirow{2}{*}{ I to 4-years } & Male & 118 & 8.02 & 9.25 & 4.93 & 65.71 \\
\hline & Female & 90 & 7.99 & 8.11 & 5.34 & 33.68 \\
\hline \multirow{2}{*}{5 to 9-years } & Male & 44 & 8.98 & 10.12 & 4.93 & 41.07 \\
\hline & Female & 37 & 8.57 & 9.09 & 5.75 & 36.14 \\
\hline \multirow{2}{*}{10 to 19 -years } & Male & 133 & 8.21 & 8.05 & 5.75 & 41.89 \\
\hline & Female & 116 & 8.55 & 7.89 & 6.16 & 36.96 \\
\hline \multirow{2}{*}{20 to 29 -years } & Male & 683 & 9.60 & 8.46 & 7.39 & 72.28 \\
\hline & Female & 430 & 8.23 & 6.33 & 6.57 & 35.32 \\
\hline \multirow{2}{*}{30 to 39 -years } & Male & 2365 & 10.04 & 7.37 & 8.21 & 87.06 \\
\hline & Female & 1019 & 9.34 & 6.80 & 8.21 & 43.53 \\
\hline \multirow{2}{*}{40 to 49 -years } & Male & 5914 & 10.29 & 6.96 & 9.03 & 80.49 \\
\hline & Female & 2662 & 9.93 & 7.44 & 8.21 & 105.13 \\
\hline \multirow{2}{*}{50 to 59 -years } & Male & 10423 & 10.42 & 6.95 & 9.03 & 101.85 \\
\hline & Female & 5195 & 10.24 & 7.42 & 9.03 & 94.46 \\
\hline \multirow{2}{*}{60 to 69 -years } & Male & 11842 & 10.30 & 7.06 & 9.03 & 83.78 \\
\hline & Female & 7025 & 10.25 & 7.21 & 9.03 & 81.31 \\
\hline \multirow{2}{*}{70 to 79 -years } & Male & 8859 & 9.83 & 6.67 & 8.21 & 87.06 \\
\hline & Female & 5589 & 9.47 & 6.85 & 8.21 & 91.17 \\
\hline \multirow{2}{*}{80 to 89 -years } & Male & 3982 & 8.94 & 6.41 & 7.39 & 80.49 \\
\hline & Female & 2729 & 8.44 & 6.28 & 7.39 & 82.96 \\
\hline \multirow{2}{*}{90 -years and above } & Male & 578 & 7.90 & 6.66 & 6.57 & 82.96 \\
\hline & Female & 498 & 7.77 & 5.66 & 6.57 & 37.78 \\
\hline \multicolumn{7}{|c|}{$\begin{array}{l}\text { SD: Standard deviation; * Maximum duration, starting from zero that patients were } \\
\text { alive (onset of symptoms to fatality) }\end{array}$} \\
\hline
\end{tabular}

Male patients survived longer period on average after the onset of symptoms than females. Highest number of days that patients were alive has been observed among male patients in the age group 50-59-years (10.42-days) and among females it was in the age group 60-69-years (10.25-days). A pattern of relatively lower number of days of such duration (onset of symptom to outcome) was found below 20-years and above 80 years of age $(<9$-days) (Figure 1). Correlation between the duration that patients were alive and $\operatorname{sex}($ male $=1$, female $=2)$ was significant (point biserial correlation coefficient $=-0.03, p<0.05)$ that was consistent with the pattern observed in the Figure 1.

\section{DISCUSSION}

The present study demonstrates sex difference in the number of days that patients were alive after SARS-CoV-2 infection by age groups in Mexican population. The results were consistent with the reports from different countries showing higher mortality in 


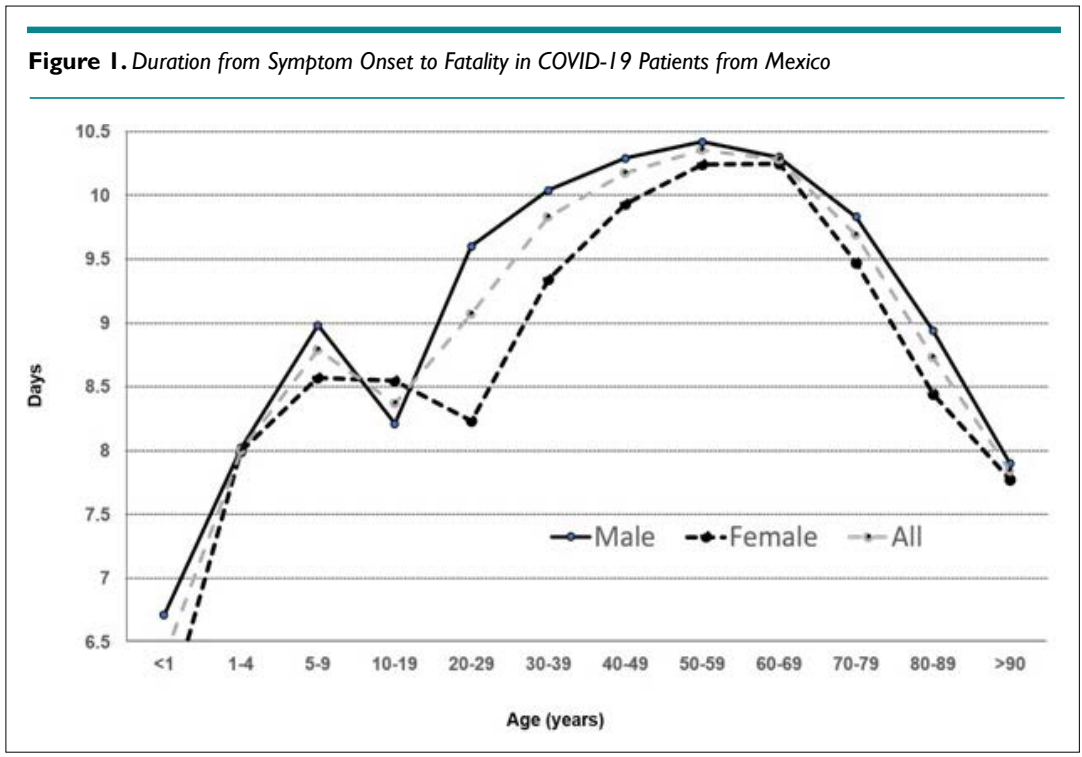

males compared to females in COVID-19. ${ }^{8}$ Our findings according to specific age group survival are consistent with the reports from different countries showing that male and female patients have similar susceptibility of being infected by age; however, higher number of males are being infected by SARS-Cov- $2 .{ }^{8}$ We observed a lower median survival time (symptom onset to death) (8.21-days) when comparing the duration of hospital stay among non-survivors (12.7-days, ranging between 0.8 and 32.9-days) reported from the U.S.A. ${ }^{6}$ Another study from China among adult COVID-19 patients reported average duration from symptom onset to release from quarantine was $20.2 \pm 6.6$-days. ${ }^{9}$ In the present study, average duration (symptom onset to fatal outcome) was 9.91-days.

A review on sexual dimorphism in the susceptibility of infection showed higher number of infected cases and deaths among male patients due to COVID-19 across the world. ${ }^{1}$ It has been observed in the current pandemic caused by the etiological agent SARS-CoV-2 that males present higher number of positive cases compared to the cases reported among female patients showing a male-to-female ratio 1.93:1. ${ }^{10}$ Sex differences in the comorbidities and lifestyle habits in COVID-19 are also reported. ${ }^{11}$ In general, risk behaviors including smoking and alcoholism are higher among men than woman that are associated with mortality. ${ }^{11,12}$ Studies on sex differentials in disease susceptibility due to genetic, epigenetic, immunological, and endocrinological factors showed that males were more susceptible to infections by different pathogens such as virus, compared to females. ${ }^{13-15}$

The present study shows number of deaths due to COVID-19 was higher among adults that was more noticeable in 50 -years of age and above. It has been reported earlier that patients of older age ( $\geq 65$-years) had higher risk of death due to comorbidities like diabetes, chronic obstructive pulmonary disease (COPD), cardiovascular, and renal diseases. ${ }^{16-18}$ Patients of advanced age with chronic diseases like diabetes and cardiorespiratory disorders are more vulnerable than young individuals in this pandemic. ${ }^{18,19}$

Disease outcome in COVID-19 might be worse in females as it is evident in the present study that female patients sur- vived lower number of days after the onset of symptoms compared to the male peers except in the age group 10-19-years. This fact can be explained in the light of the information available in the database of Ministry of Health, Federal Government of Mexico $^{7}$ that showed majority of the patients had been hospitalized (males $89.1 \%$, females $89.7 \%$ ) and on average, $14.23 \%$ received life support in the intensive care unit (ICU), and $21.62 \%$ patients received endotracheal intubation. Higher number of children and adolescents received support in the ICU (14 to 33\%) compared to adults (7 to $13 \%)$. The highest percentage of hospitalized individuals was found in 2-5 age group: (95\% boys, 96.55\% girls). The principal comorbidity across the age was pneumonia (males $70.45 \%$, females $71.75 \%$ ). It was interesting to observe that adult male patients had higher mortality despite sex-bias in the prevalence of chronic diseases for women: arterial hypertension (men $36.20 \%$, women $45.21 \%$ ), obesity (men $19.70 \%$, women $24.49 \%$ ), diabetes (men $28.15 \%$, women $35.36 \%$ ), and COPD (men $5.43 \%$, women $6.76 \%$ ).

It is worthy to mention the shortcomings of the present study. Association of socio-demographic characteristics and lifestyle habits with COVID-19 mortality, regional, ethnic, rural, and urban differences from different Mexican States could enrich the results that will be explored in future studies.

\section{CONCLUSION}

Female patients were alive fewer number days after infection in comparison with male peers that seems to be caused by the femalebias in the comorbidities despite higher mortality among male patients of COVID-19 in Mexico.

\section{AUTHORS' CONTRIBUTIONS}

All authors had equal contribution to prepare the manuscript.

\section{FUNDING}

This work did not receive any financial support. 


\section{CONFLICTS OF INTEREST|}

The authors declare no competing interest with respect to the research, authorship and/or publication of this article.

\section{REFERENCES}

1. Datta-Banik S. Sexual dimorphism in the susceptibility to infections: "Being a male is a risk factor" for SARS-Cov-2 infection.J Life Science. 2020; 12(1-2): 12-19. doi: 10.31901/24566306.2020/12.12.253

2. Mendez-Dominguez N, Alvarez-Baeza A, Carrillo G. Demographic and health indicators in correlation to interstate variability of incidence, confirmation, hospitalization, and lethality in Mexico: Preliminary analysis from imported and community acquired cases during COVID-19 outbreak. Int J Environ Res Public Health. 2020; 17: 4281. doi: 10.3390/ijerph17124281

3. World Health Organization (WHO). WHO Coronavirus Disease (COVID-19) Dashboard. 2020. Web site. https://covid19. who.int/. Accessed August 29, 2020.

4. Covid-19 México. Gobierno Federal de México. Web site. https://coronavirus.gob.mx/datos/. Accessed August 15, 2020.

5. Carrillo G, Mendez-Dominguez N, Santos-Zaldivar KD, Perez AR, Morales MA, Koh OC, et al. Clinical course and severity outcome indicators among COVID 19 hospitalized patients in relation to comorbidities distribution Mexican cohort. Med Rxiv. 2020; (In Press).Preprint. doi: 10.1101/2020.07.31.20165480

6. Lewnard JA, Liu VX, Jackson ML, Schmidt MA, Jewell BL, Flores JP, et al. Incidence, clinical outcomes, and transmission dynamics of severe coronavirus disease 2019 in California and Washington: Prospective cohort study. BMJ. 2020; 369: m1923. doi: 10.1136/bmj.m1923

7. Dirección General de Epidemiología. Datos Abiertos - Bases históricas: COVID-19: 15 de agosto del 2020. Web site. https:// www.gob.mx/salud/documentos/datos-abiertos-bases-historicasdireccion-general-de-epidemiologia. Accessed August 15, 2020.

8. Gargaglioni LH, Marques DA. Let's talk about sex in the context of COVID-19. J Appl Physiol. 2020; 128: 1533-1538. doi: 10.1152/ japplphysiol.00335.2020

9. Tian S, Chang Z, Wang Y, Wu M, Zhang W, Zhou G, et al. Clinical characteristics and reasons for differences in duration from symptom onset to release from quarantine among patients with COVID-19 in Liaocheng, China. Front Med. 2020; 7: 20. doi:

\section{$10.3389 /$ fmed.2020.00210}

10. Nikpouraghdam M, Farahani AJ, Alishiri GH, Heydari S, Ebrahimnia M, Samadinia H, et al. Epidemiological characteristics of coronavirus disease 2019 (COVID-19) patients in IRAN: A single center study. J Clin Virol. 2020; 127: 104378. doi: 10.1016/j. jcv.2020.104378

11. Heise L, Greene ME, Opper N, Stavropoulou M, Harper C, Nascimento $\mathrm{M}$, et al. Gender inequality and restrictive gender norms: framing the challenges to health. Lancet. 2019; 393(10189): 2440-2454. doi: 10.1016/S0140-6736(19)30652-X

12. Zheng Z, Peng F, Xu B, Zhao J, Liu H, Peng J, et al. Risk factors of critical \& mortal COVID-19 cases: A systematic literature review and meta-analysis. J Infect. 2020; 81: e16-e25. doi: 10.1016/j. jinf.2020.04.021

13. Klein SL, Huber S. Sex differences in susceptibility to viral infection. In: Klein SL, Roberts C, eds. Sex Hormones and Immunity to Infection. Berlin, Heidelberg: Springer; 2010: 93-122.

14. Libert C, Dejager L, Pinheiro I. The X chromosome in immune functions: When a chromosome makes the difference. Nat Rev Immunol. 2010;10, 594-604. doi: 10.1038/nri2815

15. Weckerle CE, Niewold TB. The unexplained female predominance of systemic lupus erythematosus: Clues from genetic and cytokine studies. Clin Rev Allergy Immunol. 2011; 40(1): 42-49. doi: 10.1007/s12016-009-8192-4

16. Du RH, Liang LR, Yang CQ, Wang W, Cao T-Z, Li M, et al, Predictors of mortality for patients with COVID-19 pneumonia caused by SARS-CoV-2: A prospective cohort study. Eur Resp J. 2020; 55: 2000524. doi: 10.1183/13993003.00524-2020

17. Zhou F, YuT, Du R, Fan G, Liu Y, Liu Z, et al. Clinical course and risk factors for mortality of adult inpatients with COVID-19 in Wuhan, China: A retrospective cohort study. Lancet. 2020; 395: 1054-1062. doi: 10.1016/S0140-6736(20)30566-3

18. Yang J, Zheng Y, Gou X, Pu K, Chen Z, Guo Q, et al. Prevalence of comorbidities and its effects in patients infected with SARS-CoV-2: A systematic review and meta-analysis. Int J Infect Dis. 2020; 94: 91-95. doi: 10.1016/j.ijid.2020.03.017

19. Jayawardena R, Sooriyaarachchi P, Chourdakis M, Jeewandara $\mathrm{C}$, Ranasinghe $\mathrm{P}$, et al. Enhancing immunity in viral infections, with special emphasis on COVID-19: A review. Diabetes Metab Syndr. 2020; 14: 367-382. doi: 10.1016/j.dsx.2020.04.015 